\title{
Effect of magnesium pemoline on avoidance conditioning and intertrial activity in two strains of inbred mice ${ }^{1}$
}

\section{T. YEUDALL, WAYNE POLEY, and J. $R$. ROYCE, University of Alberta, Edmonton, Canada}

Magnesium pemoline was found to have a differential effect on behavior depending upon genotype. The drug resulted in increased activity and reduced avoidance scores for the fast-conditioning $\mathrm{C} 3 \mathrm{H}$ strain of mice, whereas it significantly increased avoidance scores and activity for the slow-conditioning ST/bJ strain. The effect of magnesium pemoline on behavior is discussed in terms of an inverted- $U$ relationship between reactivity and learning.

Since Plotnikoff's (1966) first study on the effect of magnesium pemoline on avoidance learning, there have been several studies (Powell et al, 1967; Beach \& Kimble, 1967; Frey \& Polidora, 1967; Kulkarni, 1967; Thompson \& Knudson, 1968; Wimer, 1968) demonstrating that magnesium pemoline does affect behavior. The interpretation of its effects has centered around the distinction between performance and learning. Other studies have failed to demonstrate any effect of magnesium pemoline on behavior (Chase \& Rescorla, 1968; Gurowitz et al, 1967; McCarroll \& Korbel, 1968; Cyert et al, 1967). The conflicting results are not at all surprising when one finds variation in these studies in terms of species of animals used, drug dosages, administration route of the drug, training procedures, apparatuses, dependent variables, criterion of learning, and such conditioning parame ters as shock intensity, scrambled vs nonscrambled shock, CS, UCS and intertrial intervals, and type of CS employed. Considering these differences, one would expect animals to freeze in some studies because of low-intensity shocks and/or use of nonscrambled shock. Also, genetic factors should be considered. The animals used in most studies were probably not homozygous lines; thus, one would expect a certain proportion of the animals to manifest freezing behavior. It could also be argued that the jump-out and one-way active-avoidance tasks represent overly simple problems. The tasks would have a low ceiling effect that would mask the effect of the drug. A similar ceiling effect could be operating in terms of the learning capacity (high or low) of the organism, determined by its genotype. In the studies reviewed, there has been reference only to slow learners and to freezing animals, without any reference to the possibility that the "fast" learners could not be affected by the drug because of a ceiling effect imposed by their genotype (Royce, 1966).

The present study is an attempt to control some of the factors that could confound the interpretation of the data. This was done by using fast- and slow-conditioning inbred strains of mice to assess the effect of the drug on different genotypes, a high level $(400 \mathrm{~V})$ of shock, scrambled to reduce the possibility of freezing behavior, and a two-way (nonhurdle) active-avoidance shuttlebox to increase the task complexity. To counterbalance the increased activity of magnesium pemoline animals, the shock period remained on for an additional $10 \mathrm{sec}$ after the normal CS and UCS intervals, on the side of the apparatus from which the animal had just avoided or escaped. If an animal returned to the unsafe side during this $10-\sec$ period, it received a shock, and the trial was recorded as an error. Thus, increased motor activity per se would result in more intertrial responses and more errors.

\section{EXPERIMENT 1}

The purpose of this experiment was to establish dosage-response curves for magnesium pemoline. Conditioning of the $\mathrm{C}_{3} \mathrm{H}$ strain was studied over 14 consecutive days of training.

\section{Subjects}

Thirty-five naive mice, 18 males and 17 females drawn from our $\mathrm{C}_{3} \mathrm{H}$ inbred stock, formerly obtained from Jackson Laboratories, were housed in individual cages. The Ss were between $\mathbf{4 5}$ and 50 days of age at the beginning of testing. All Ss were maintained on an ad lib diet for food and water.

The apparatus used in this study was a two-way active-avoidance shuttlebox that was fully automated (Yeudall, Royce, \& De Leeuw, 1968). The voltage was fixed at $400 \mathrm{~V}$ ac (matched impedance circuit with a $220 \mathrm{~K} \mathrm{ohm}$ resistor), the CS (electronic buzzer at $85 \mathrm{~dB}$ ) duration was $3 \mathrm{sec}$, the UCS duration was $10 \mathrm{sec}$, and the intertrial interval was $20 \mathrm{sec}$. A delayed-conditioning procedure was employed, and all training was conducted under $85 \mathrm{~dB}$ of white noise.
Table 1

Correct Avoidances and Inter-Trial Activity for Experiment 1

\begin{tabular}{lcr}
\hline & Avoidances & I.T.A. \\
\hline Control & 19.3 & 3.4 \\
$1 \mathrm{mg} / \mathrm{kg}$ & 21.4 & 3.4 \\
$5 \mathrm{mg} / \mathrm{kg}$ & 19.6 & 6.1 \\
$10 \mathrm{mg} / \mathrm{kg}$ & 23.0 & 5.2 \\
$20 \mathrm{mg} / \mathrm{kg}$ & 14.4 & 14.7 \\
$30 \mathrm{mg} / \mathrm{kg}$ & 14.6 & 11.3 \\
\hline
\end{tabular}

Intertrial activity was recorded by two banks of photocells located in the center of the apparatus.

\section{Procedure}

The Ss were assigned to 1-, 5-, 10, 20 (three males and three females in each group), and 30- (three males and two females) $\mathrm{mg} / \mathrm{kg}$ magnesium pemoline drug groups and to a normal saline group. The magnesium pemoline was suspended in $0.3 \%$ tragacanth, and each animal received approximately $.25 \mathrm{cc}$ of solution with daily injections. On each day, Ss were injected intraperitoneally $30 \mathrm{~min}$ prior to training. The Ss were given 25 conditioning trials a day for 14 consecutive days.

\section{Results}

The data were analyzed according to a 2 by 6 by 14 analysis of variance, with main effects for sex, dosage, and days of training. Sex was not found to be significant for either correct avoidances or intertrial activity. Since the main effects for correct avoidance and intertrial activity approached significance $\quad(F=2.36$, $\mathrm{df}=5 / 24, \mathrm{p}<.07$ and $\mathrm{F}=2.54, \mathrm{df}=5 / 24$, $\mathrm{p}<.06$, respectively), the last 3 days were analyzed using Duncan's multiple-range test. For conditioning, the 20 and $30-\mathrm{mg} / \mathrm{kg}$ groups made significantly fewer avoidances than the control group $(p<.05)$. Similarly, for activity, the 20 and $30 \mathrm{mg} / \mathrm{kg}$ groups made significantly more intertrial responses during the last 3 days of training $(p<.05)$ (see Table 1 for mean scores of correct avoidances and intertrial activity of the control and drug groups). Intertrial activity was found to correlate negatively with correct avoidances $(r=-.64, \mathrm{df}=34, \mathrm{p}<.01)$.

\section{EXPERIMENT 2}

In the first experiment, magnesium pemoline was found to have a detrimental effect on learning. As $\mathrm{C}_{3} \mathrm{H}$ is generally found to be a fast-conditioning strain (Royce \& Covington, 1960), it was hypothesized that the learning ceiling (as determined by a genetic mechanism) was too low, and the drug could not manifest its possible facilitating effect on learning. This experiment employed a slow-conditioning strain of mice (ST/bJ), with intermediate dosages of 8 and $16 \mathrm{mg} / \mathrm{kg}$ of magnesium pemoline. 
Table 2

Correct Avoidances and Inter-Trial Activity for Experiment 2

\begin{tabular}{lcrrrr} 
& \multicolumn{2}{c}{ Acquisition } & & \multicolumn{2}{c}{ Retraining } \\
\cline { 2 - 3 } Group & Avoidances & ITR's & & Avoidances & ITR's \\
\hline Control & 3.6 & 8.6 & 6.1 & 9.2 & 14.7 \\
$8 \mathrm{mg} / \mathrm{kg}$ & 8.3 & 11.6 & 5.7 & 13.3 \\
$16 \mathrm{mg} / \mathrm{kg}$ & 7.8 & 10.4 & & 7.4 \\
\hline
\end{tabular}

Subjects and Apparatus

Twenty-seven naive mice of the ST/bJ inbred strain, raised in our laboratory, were housed in individual cages up to and through training. The Ss were between 65 and 75 days of age at the beginning of testing. The same apparatus was used as in the first experiment.

\section{Procedure}

Nine Ss were randomly assigned (approximately balanced for sex) to the 8and $16-\mathrm{mg} / \mathrm{kg}$ drug groups and to a control group that was injected with $0.3 \%$ tragacanth. The same avoidance parameters and procedures were employed as in the first experiment. The Ss were trained for 7 consecutive days and then retested 14 days later for 5 consecutive days. Drug injections terminated on the 7th day of drug acquisition training. All Ss were weighed prior to testing and after the last day of retesting.

\section{Results}

The data were analyzed according to a 3 by 7 analysis of variance, with main effects for dosage and days of training, and a 3 by 5 analysis for retesting. Dosage levels over all days of training approached significance for correct avoidances during the drug acquisition period of training $(F=3.1, \quad d f=2 / 24, p=.06)$. Significant differences were found between Day 1 and Day 7 means for correct avoidances for the
8- and 16-mg/kg groups $(\mathrm{p}=.008$ and .007 , respectively), whereas no increase in correct avoidances occurred for tragacanth controls. During retraining without the drug, the dosage level over all 5 days had a significant effect $(F=3.6, \quad d f=2 / 24$, $\mathrm{p}=.04)$. The $16-\mathrm{mg} / \mathrm{kg}$ group manifested a significant decrease in correct avoidances $(\mathrm{p}=.03)$, whereas the $8-\mathrm{mg} / \mathrm{kg}$ and control groups' decrease in avoidance was not significant.

Magnesium pemoline, at both dosage levels, was found to significantly increase intertrial activity during the drug-acquisition phase $(F=4.3, \mathrm{df}=2 / 24$, $\mathrm{p}<.05)$. During retesting, the $16-\mathrm{mg} / \mathrm{kg}$ drug group made significantly fewer intertrial responses, whereas the $8-\mathrm{mg} / \mathrm{kg}$ group did not differ from either the $16-\mathrm{mg} / \mathrm{kg}$ group or the control group. Intertrial activity in the drug-acquisition phase correlated significantly with correct avoidances $(\mathrm{r}=+0.52, \mathrm{df}=26, \mathrm{p}<.01)$, whereas, during retesting, intertrial activity did not correlate with avoidances $(\mathrm{r}=-.05, \mathrm{df}=26, \mathrm{p}>.05)$.

Weights of the Ss were analyzed according to a 3 by 2 analysis of variance. Although the Ss were significantly heavier at the completion of the experiment $(F=6.1, \mathrm{df}=1 / 24, \mathrm{p}<.05)$, the Dosage by Replication interaction was not significant $(F=1.4, \mathrm{df}=2 / 24, \mathrm{p}>.05)$,

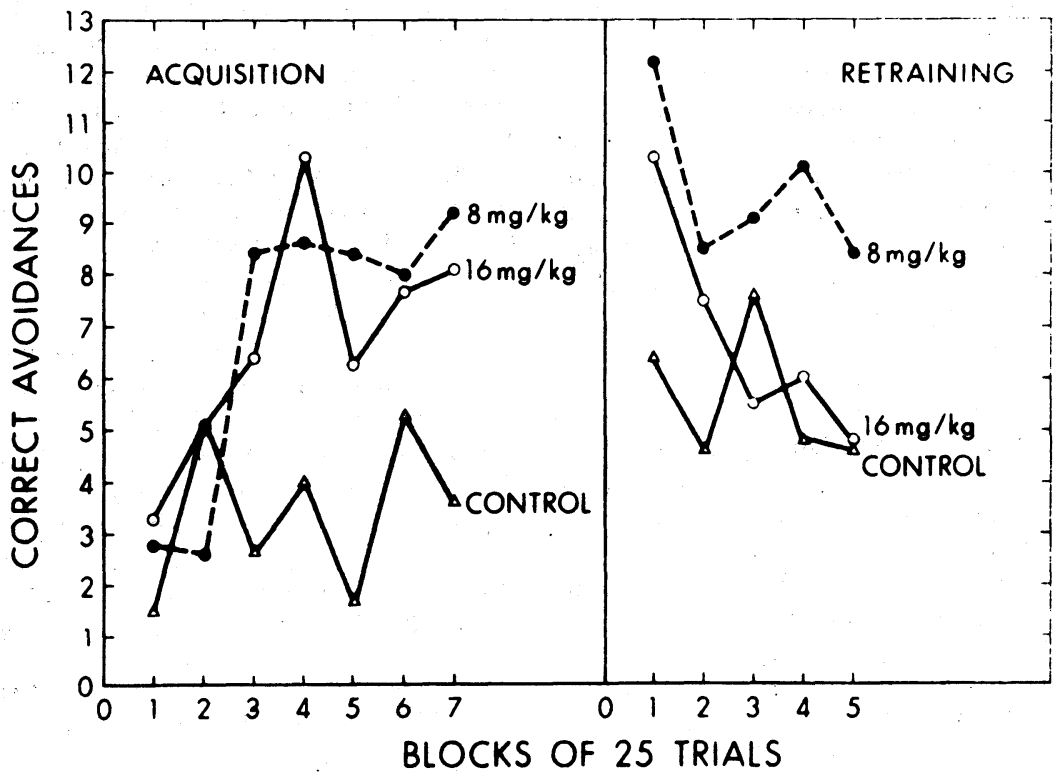

indicating that magnesium pemoline did not differentially affect the weight of the Ss. DISCUSSION

These findings support the conclusions of others (Beach \& Kimble, 1967; Frey \& Polidora, 1967; Boitano \& Boitano, 1967; etc.) that magnesium pemoline increases general motor activity. The present study was designed so that an increase in motor activity (as manifested by intertrial activity) would result in poorer performance. The paradigm dictated that motor inhibition must occur for at least $10 \mathrm{sec}$ after a correct response if the $\mathrm{S}$ was to avoid making an incorrect response. Under these conditions, the fast learners exhibited poorer performance as the dosage level of the drug was increased. It is hypothesized that the $\mathrm{C}_{3} \mathrm{H}$ strain has a low genetic ceiling in regard to an arousal threshold or to a motor-activation system. Thus, the higher levels of magnesium pemoline produced an excess of excitation in these systems that exceeds the optimal levels of arousal for maximum performance. Conversely, in the case of the $\mathrm{ST} / \mathrm{bJ}$, slow-conditioning strain, it is hypothesized that these animals have a high ceiling in regard to an arousal or motor-activation threshold, so that the increased excitation due to the magnesium pemoline was beneficial to learning. The significant retention of the $8-\mathrm{mg} / \mathrm{kgST} / \mathrm{bJ}$ animals in Experiment 2 suggests that the drug had some effect on the learning process, as well as affecting performance. The $16-\mathrm{mg} / \mathrm{kg}$ group, on the other hand, manifested state-dependent behavior since their performance dropped.

The correlations reported in the study also support this interpretation. $\mathbf{A}$ significant negative correlation between conditioning and activity was found in the $\mathrm{C}_{3} \mathrm{H}$ strain. On the other hand, a significant positive correlation was found for 7 days of acquisition in the ST/bJ Ss. When injection was terminated during retesting of the $S T / b J$ Ss, no significant correlation was found. These results indicate that magnesium pemoline had an arousal effect, and that this effect was detrimental to learning in the fast-conditioning Ss but beneficial to learning in the slow-conditioning Ss.

The hypothesis of a genetic ceiling, interpreted in an emotionality framework in this study, is congruent with the findings of Carran, Yeudall, \& Royce (1964), where a correlation between avoidance learning and skin-resistance changes was found in fast- and slow-conditioning mice. If one assumes that GSR changes are reflective of changes in arousal or activation in the

Fig. 1. Avoidances by day for Ss in Experiment 2. 
central nervous system, then it seems plausible that the emotional reactivity of the fast-conditioning $\mathrm{C}_{3} \mathrm{H}$ strain is close to an optimal level (in terms of an inverted-U function), so that magnesium pemoline increases activation beyond its optimal level, resulting in a decrement of performance. However, in the ST/bJ strain, magnesium pemoline increases the "emotional reactivity" to a level that is facilitatory for learning and performance in terms of the inverted-U function.

\section{REFERENCES}

BEACH, G., \& KIMBLE, D. P. Activity and responsivity in rats after magnesium pemoline injections. Science, 1967, 151, 698-701.

BOITANO, J. J., \& BOITANO, J. C. Magnesium pemoline: Enhancement of spontaneous motor activity. Psychonomic Science, 1967, 9, 295-296.

CARR AN, A. B., YEUDALL, L. T., \& ROYCE, J. R. Voltage level and skin resistance in avoidance conditioning in inbred strains of mice. Journal of Comparative \& Physiological Psychology, 1964, 58, 427-430.

CHASE, T. C., \& RESCORLA, R. A. The effect of magnesium pemoline on learning an active avoidance-passive avoidance discrimination. Psychonomic Science, 1968, 10, 87-88.

CYERT, L. A., MOYER, K. E., \& CHAPMAN, J. A. Effect of magnesium pemoline on learning and memory of a one-way avoidance response. Psychonomic Science, 1967, 7, 9-10.

FREY, P. W., \& POLIDORA, V. J. Magnesium pemoline: Effect on avoidance conditioning in rats. Science, 1967, 155, 1281-1282.

GUROWITZ, E. M., LUBAR, J. F., AIN, B. R., \&
GROSS, D. A. Disiuption of passive avoidance learning by magnesium pemoline. Psychonomic Science, 1967, 8, 19-20.

KULKARNI, A. S. Magnesium pemoline: Facilitation of instrumental avoidance learning. Psychonomic Science, 1967, 9, 39-40.

McCARROLL, J. E., \& KORBEL, S. F. Magnesium pemoline: Effects on the learning and retention of a conditioned avoidance response by rats. Psychonomic Science, 1968, $11,233-234$.

PLOTNIKOFF, $\quad \mathrm{N}$. Magnesium pemoline: Enhancement of learning and memory of a conditioned avoidance response. Science, 1966, 151, 703-704.

POWELL, B. J., MARTIN, L. K., \& KAMANO, D. K. More on magnesium pemoline: Differential effects of advance and immediate injections on avoidance performance. Psychonomic Science, 1967, 8, 303-304.

ROYCE, J. R. Optimal stimulus parameters in avoidance conditioning of inbred strains of mice. Multivariate Behavioral Research, 1966, 1, 209-217.

ROYCE, J. R., and COVINGTON, M. Genetic differences in the avoidance conditioning of mice. Journal of Comparative \& Physiological Psychology, 1960, 53, 197-200.

THOMPSON, R., \& KNUDSON, G. R. Magnesium pemoline: Facilitation of one way and two way avoidance learning. Psychonomic Science, 1968, 11, 155.

WIMER, C. Magnesium pemoline: Effects on active and passive avoidance conditioning in mice. Psychonomic Science, 1968, 12, 23-24.

YEUDALL, L. T., ROYCE, J. R., \& De LEEUW, $M$. An automatic apparatus for avoidance-conditioning. Psychological Reports, $1968,22,139142$.

\section{Cage activity in the California antelope ground squirrel}

A. L. CONE and DONNA M. CONE, Lynchburg College, Lynchburg, Va. 24504

Cage activity of six California antelope ground squirrels was measured twice daily (moming and night) under six levels of ambient illumination (dark, less than 1.0, 2.5, 5.0, 25.0, 50.0 ft-c). Analysis of variance indicated that the Ss were significantly more active in the morning than at night under all levels of illumination. In addition, the Illumination by Time of Day interaction was significant. Increasing levels of illumination produced decreasing cage activity in the morning, but did not significantly affect cage activity at night. Results are discussed in comparison to earlier measures of cage activity with the nocturnal Virginia opossum.
Cone \& Cone (1968) have reported that the effects of ambient illumination on the cage activity of the opossum (Didelphis virginiana) are not independent of the phase of the organism's circadian cycle. As illumination was increased above a range of $2 \frac{1}{2}$ to $5 \mathrm{ft}-\mathrm{c}$, cage activity during the nighttime (10 p.m. to midnight) decreased, while cage activity during the daytime (10 a.m. to noon) increased. The authors interpreted these finding in terms of Bindra's hypothesis (1959) that the relationship between arousal level and performance is best described as an inverted U-shaped curve. They contended that nocturnal animals, such as the opossum, experience optimal arousal at night under low levels of illumination, and that increasing illumination during this peak nighttime arousal period produced an arousal level high enough to lower cage activity. On the other hand, increasing illumination during the relatively low arousal day time period produced an increase in arousal level sufficient to raise cage activity. In contrast to nocturnal animals, diurnal animals reach peak activity during the daytime (Marler \& Hamilton, 1966). Thus, optimal arousal in a diurnal animal would appear to be associated with daytime and intermediate levels of illumination. Increasing illumination during the peak day time arousal period in a diurnal animal should produce an arousal level high enough to lower cage activity, while the same increase in illumination at night should increase arousal sufficiently to raise cage activity. To test this hypothesis, the present replication of the opossum study was conducted using a diurnal rodent, the California an telope ground squirrel/Citellus leucurus leucurus).

\section{SUBJECTS}

The Ss were six adult ground squirrels, four males and two females, randomly selected from a colony of 12 animals. This colony had been obtained from the White Animal Farm in Maine and adapted to the laboratory for 2 weeks prior to the selection. The Ss were maintained on an ad lib diet of Purina rat chow and water throughout the experiment.

\section{APPARATUS}

Each S's living cage, a round wire-mesh enclosure 9 in. in diam and 9 in. high, was placed on a Lehigh Valley Electronics Company jiggle platform on top of a table in a sound-treated room. Each cage unit was separated from the other units by plywood partitions. The room was ventilated by an exhaust fan which also provided masking noise. The broad-band intensity of the noise was $82 \mathrm{~dB}$ as measured by a General Radio Sound Survey Meter; the low frequencies. contributed more than did the high frequencies to the overall noise level. The temperature of the test room was constantly monitored with a Bachrach Tempscribe and did not vary more than $4 \operatorname{deg} C$ during the experiment.

Eight inches above the wire-mesh top of each cage, a light-diffusing screen made of four layers of white tissue paper was placed. Six inches above the tissue paper, there was mounted a light socket into which bulbs of various wattages were inserted for the different levels of illumination. Levels of illumination were measured with a Weston Model 703 footcandle meter placed at the center of each cage. The six experimental levels of illumination were dark, less than 1 , $21 / 2,5,25$, and $50 \mathrm{ft}-\mathrm{c}$; the houselight was approximately $15 \mathrm{ft}-\mathrm{c}$.

Cage activity was automatically recorded on electromechanical counters from 10 p.m. 